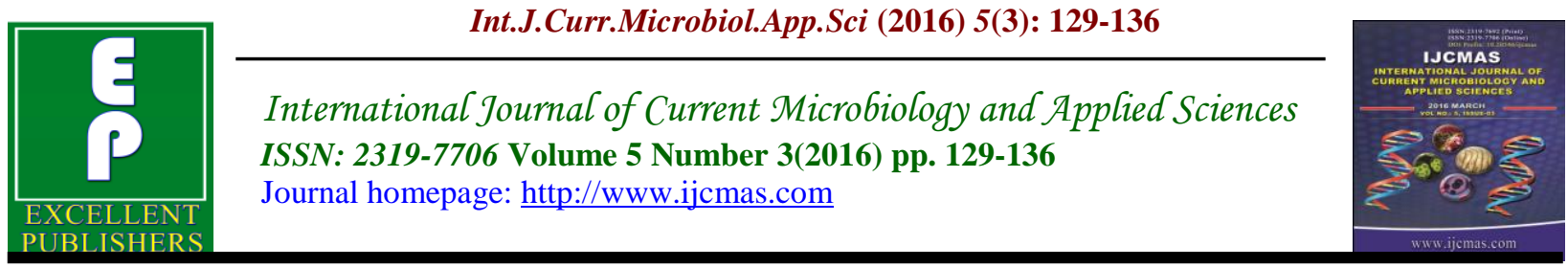

Original Research Article

http://dx.doi.org/10.20546/ijcmas.2016.503.018

\title{
Prevalence, Bacteriology, Pathogenesis and Isolation of $E$. coli in Sick Layer Chickens in Ajmer Region of Rajasthan, India
}

\author{
Tripti Dadheech $^{1 *}$, Reena Vyas ${ }^{1}$, Vijaylatha Rastogi $^{2}$ \\ ${ }^{1}$ Department of Zoology, Govt. College Ajmer, India \\ ${ }^{2}$ Microbiology Department, Jawahar Lal Nehru Medical College, Ajmer, India \\ *Corresponding author
}

\begin{abstract}
A B S T R A C T
Keywords

Collibacillosis,

Bacteriology,

Biochemical

Characterization,

Prevalence, Infection.

Article Info

Accepted:

12 February 2016

Available Online:

10, March 2016

A study was conducted to determine the distribution of $E$. coli in visceral organs of clinically sick chickens (Gallus gallus). A total of 24 tissue samples consisting of 6 liver, 12 small intestine, and 6 large intestine samples were aseptically collected from 12 fowls of 4 selected poultry farms of Ajmer suspected for colibacillosis and subjected to bacteriology and biochemical examination. $24 \mathrm{E}$. coli isolates were isolated following standard procedures. Processed tissue from each sample was cultured primarily on Brain Heart Infusion (BHI) broth and then secondarily on 7\% defibrinated sheep blood (Blood Agar) and MacConkey agar. Presumptive colonies of bacterial agents on media plates were subjected to conventional biochemical characterization. The result of biochemical test identified the $E$. coli isolates from the samples of clinically sick chickens, almost $100 \%$. The overall prevalence of $E$. coli was $100 \%$ and high rate of infection.
\end{abstract}

\section{Introduction}

The poultry production chain has constant advances in intensive management of animals and operations technology from advances in genetics, nutrition and animal health. Higher quality products and food security ensure the credibility. However, the intensification of the production may cause an increase in pathological load and increasing health problems. Currently, enteritis and diarrhea are serious problems in broilers, especially in newborns (Almeida $e t$ al., 2007). These intestinal infections are caused by the Gram-negative bacteria, especially Escherichia coli, Pseudomonas and Salmonella, which are more prevalent in the early life of poultry and, later, in situations of bacterial flora imbalance or immune suppression (Porter, 1998).

Avian colibacillosis is responsible for large economic losses in poultry rearing resulting in low performances, weight loss, onset of egg production and mortality.

Avian pathogenic Escherichia coli (APEC), causative bacteria of colibacillosis, induces various syndromes including respiratory tract infection (airsacculitis), acute colisepticemia, salpingitis and cellulitis (Stordeur and Mainil, 2002). The most 
common form of colibacillosis occurs among 2 to 10 week-old chickens.

The intensification of poultry has lead to increased susceptibility to various disease conditions in the birds. Among these, losses due to colibacillosis appears to be one of the bottle necks as it has been recorded regularly in majority of the farms throughout the year. The organism affects multiple body system of birds causing various symptoms. The high consumption of chicken meat also warrants great care in safeguarding the industry against threatening factors (Kabir, 2010).

Avian colibacillosis, caused by Escherichia coli, is an infectious disease of birds, which is regarded as one of the main causes of morbidity and mortality, associated with heavy economic losses to poultry industry by its association with various disease conditions, either as primary pathogen or as a secondary pathogen. It causes a variety of disease manisfestations in poultry including yolk sac infection, omphalitis, respiratory tract infection, swollen head syndrome, septicemia, coligranuloma, enteritis, cellulitis and salpingitis. Colibacillosis of poultry is characterized in its acute form by septicemia resulting death and in its subacute form by peri-carditis, airsacculitis and peri-hepatitis (Calnek et al., 1997).

The poultry industries are most vulnerable to attack by Escherichia coli that increased mortality of poultry chickens. E. coli is one of the common microbial flora of gastrointestinal tract of poultry and human being including other animals but may become pathogenic to both (Jawetz et al., 1984; Levine, 1987). Major species of $E$. coli encounter in the lower portion of the intestine of human, warm blooded animals and birds, where they are mostly responsible for gastroenteritis (Pelczar et al., 1993). E. coli produces two distinct enterotoxins: a high-molecular weight, immunogenic, heat labile toxin (LT) and/or a low-molecular weight, non-immunogenic, heat stable toxin (ST) (Greenburg and Guerrant, 1986).

The bacterial count in poultry housing systems is high in comparison to those of pig and cattle. Little is known about the bacteria present in the poultry environment such as in poultry litter and air of poultry house (Saleh et al., 2003). Bacteria present in poultry environment may enter into the flock to produce disease. There are also reports indicating that poultry feed and water may act as a source for various infectious diseases (Rahman et al., 1999). In addition, poultry itself may act as a reservoir or source of infectious agent for other healthy birds. Therefore, it is important to know the prevalence and distribution of different bacterial flora in poultry and it's environment as many of them may be potential pathogen for poultry. Such information is also required to take necessary actions for the prevention and control of diseases caused by bacterial pathogens.

In view of the significance of $E$. coli infection in poultry, this study has been undertaken to isolate Escherichia coli from infected samples of layers; to study bacteriology, pathogenesis and prevalence of $E$. coli and to determine the present status of colibacillosis in layers of Ajmer region.

\section{Materials and Methods}

\section{Sampling Site}

The study was conducted in the Rasulpura area of Ajmer region. 12 layers with possible colibacillosis collected in 4 different farms were autopsied. 


\section{Autopsy}

Organs showing characteristics lesions related with colibacillosis were inspected and samples were collected randomly for further analyses.

\section{Sample Collection}

A total of 24 tissue samples from poultry chickens (layers) were collected from different poultry farms of Ajmer region, using sterile containers filled with normal saline solution for aerobic culture. The samples were preserved in ice-packs and immediately transferred to the laboratory for microbiological analysis. Samples like liver and intestine, small and large were collected aseptically from fresh carcasses exhibiting perihepatitis, enteritis, air sacculitis, yolk sac infection and pericarditis and processed for bacteriological isolation and identification.

\section{Culture and Biochemical Characterization}

Visceral organs were cultured on Brain Heart Infusion agar (Himedia) and incubated aerobically at $37^{\circ} \mathrm{C}$ for 24 hours. Suspected Escherichia coli colonies were subsequently inoculated on MacConkey Agar (Himedia) and incubated at $37^{\circ} \mathrm{C}$ for 24 hours. After incubation, the MacConkey agar plates were examined for bacterial growth. The isolates of $E$. coli were identified by observing gross colony morphology using MacConkey agar. Discrete colonies of lactose fermenting (pink) and non-lactose fermenting (cream) bacteria were identified and selected. The identification of Escherichia coli was based on the results of diagnostic tests, including Gram stain, catalase and oxidase. Selected colonies were purified on MacConkey agar, gram stained for microscopy and tested for catalase and cytochrome oxidase production. Colonies that yielded oxidase negative, catalase positive Gram-negative rods were subjected to further identification using biochemical tests kits. The E. coli organisms were identified based on their morphology, cultural, biochemical and sugar fermentation characters as per the method described by Edwards and Ewing (1972) and Cruickshank et al. (1975). Various biochemical tests which were performed include Indole test, Methyl Red (MR) test, H2S production test (TSI Agar Slant Test), Urease test and citrate utilization test. Other test like haemolysis on blood agar and motility test were also carried out.

\section{Results and Discussion}

\section{Post-Mortem Examination}

The observed lesions at necropsy were characteristic of colibacillosis. Necropsy changes and bacteriological investigation of all specimens of dead layers showed characteristic morphological and cultural properties of Escherichia coli.

\section{Isolation and Identification of $E$. coli}

From 12 suspected birds, all birds (almost $100 \%$ ) were found to be positive for E. coli infection as they show characteristic lactose fermenting colonies on Mac Conkey Agar and their biochemical and sugar fermentation characters were in accordance to Edwards and Ewing (1972). Isolates were found catalase positive and oxidase negative. The results of gross colony morphology on MacConkey Agar followed by Gram staining and motility tests are summarized in Table 1. For biochemical characterization, a series of biochemical tests, selective for $E$. coli were performed with the suspected Gram-negative rod shaped bacteria. All the isolates fermented five basic sugars producing acid and gas. All the isolates were methyl red positive, citrate negative, urease negative and indole test 
positive. The biochemical test provides confirmation for the presence of Escherichia coli in the given tissue samples, as shown in figure 3. All poultry tissue samples $(n=24)$, were found to be positive for $E$. coli isolates. In this study, the prevalence of $E$. coli in the tissue sample was $100.0 \%$ (Table 2). Appearance of large, pink, flat, circular, moist, non-mucoid LF (Lactose Fermenter) colony on MacConkey's Agar plates indicated towards the presence of
Escherichia coli, as shown in figure 1. Gram staining of LF non-mucoid colonies of such plates revealed the presence of gram negative bacilli (GNB) which supported the confirmation of the presence of Escherichia coli, as shown in figure 4 . Further, the result of motility test performed on non-mucoid LF colony picked from the above plates also confirmed the presence of $E$. coli, as the results are positive.

Table.1 Indentifying Features of E.Coli

\begin{tabular}{|l|l|c|c|c|c|}
\hline & Motility & $\begin{array}{c}\text { Colony } \\
\text { Characteristics in } \\
\text { MacConkey Agar }\end{array}$ & $\begin{array}{c}\text { Colony } \\
\text { Charecteristics } \\
\text { in Blood Agar }\end{array}$ & $\begin{array}{c}\text { Morphology and } \\
\text { Arrangement }\end{array}$ & $\begin{array}{c}\text { Staining } \\
\text { Properties }\end{array}$ \\
\hline $\begin{array}{l}\text { Poultry } \\
\text { Layer's } \\
\text { Tissue } \\
\text { Samples }\end{array}$ & Positive & $\begin{array}{c}\text { Large, Circular, } \\
\text { Pink, Flat, Moist, } \\
\text { Non-mucoid and } \\
\text { Lactose-Fermenting }\end{array}$ & $\begin{array}{c}\text { Fransparent, } \beta- \\
\text { haemolytic } \\
\text { colonies }\end{array}$ & $\begin{array}{c}\text { Short rod, single, } \\
\text { pair or in short } \\
\text { chain }\end{array}$ & $\begin{array}{c}\text { Gram } \\
\text { negative }\end{array}$ \\
\hline
\end{tabular}

Table.2 Biochemical Tests used for Identification of E.Coli

\begin{tabular}{|c|c|c|}
\hline No. of Isolates & Biochemical Test & Reaction \\
\hline \multirow{2}{*}{24} & Catalase & Positive \\
& TSI & \\
& Indole Production & \\
\hline \multirow{2}{*}{24} & Methyl Red & Negative \\
& Urease & \\
& Simmon's Citrate & $\mathrm{H}_{2} \mathrm{~S}$ \\
& Oxidase & \\
\hline
\end{tabular}

Figure.1 Pure Isolates or Colonies of Escherichia Coli on Macconkey Agar Plates

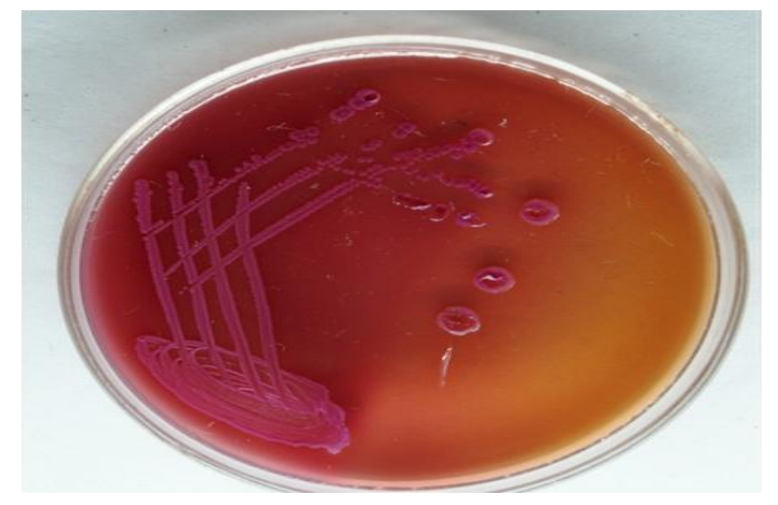


Figure.2 Inoculated Secondary Blood Agar Plates Showing Confluent or Mixed Colony Comprising of (i) Pin Head too Large, Grey-White Mucoid Colony along with Media Digestion (Black Arrow), and (ii) 6-7 Flat, Transparent, $\beta$-haemolytic Colonies of E. Coli (White Arrow)

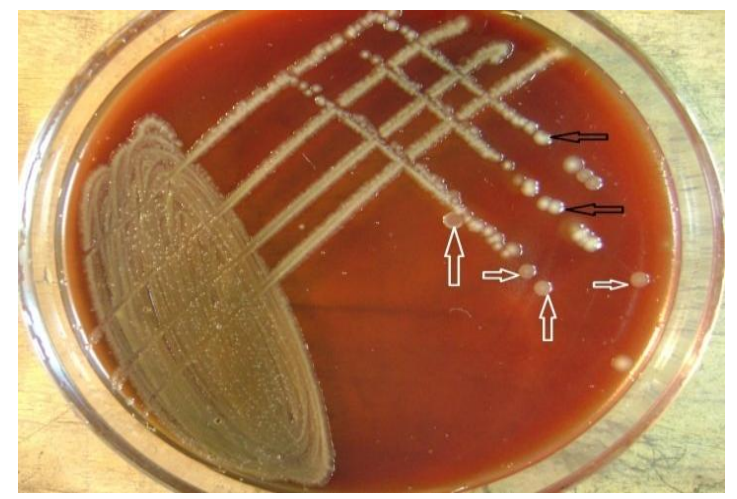

Figure.3 Lf Set of Biochemical Test (I Mr U C Tsi) from Secondary Macconkey Agar Plates Showing Positive I \& Mr Test and Negative U \& C Test and Yellow Slant/Yellow Butt with No H2s Production and with Media Pulled Upwards Due to the Intense Gas Production in Tsi Test, Confirmed the Presence of Escherichia coli in the Infected Tissue Samples

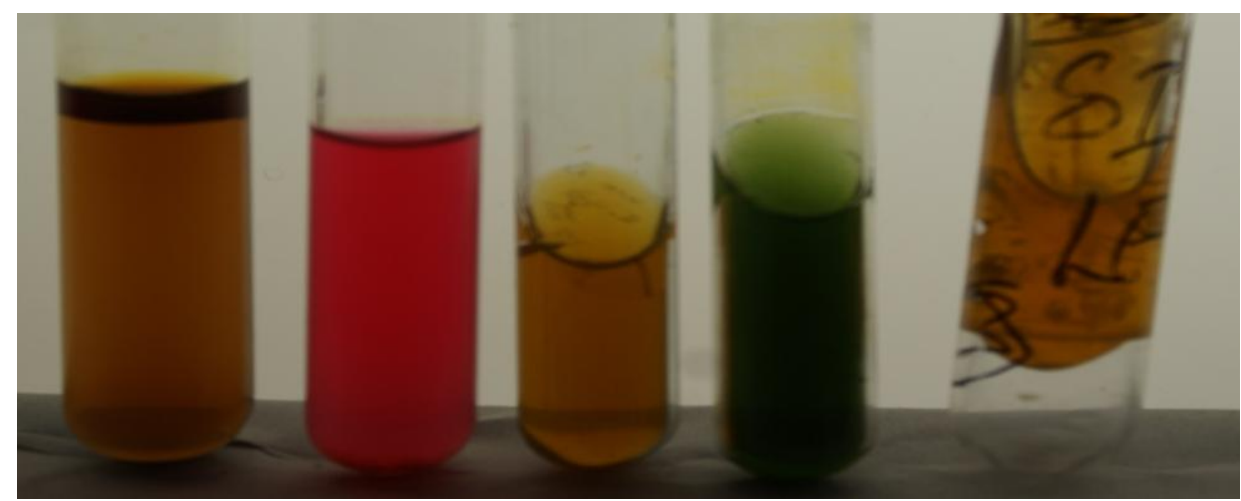

Figure.4 Photomicrography of Gram Stained Slide Prepared from Pink Flat Moist lf Colony from Secondary Macconkey Agar Plates - Black Arrow Heads Represents Numerous Gram Negative Bacilli and Dark Maroon arrow Head Represents Numerous Gram Negative Bacilli in Clusters Indicating the Presence of E. coli

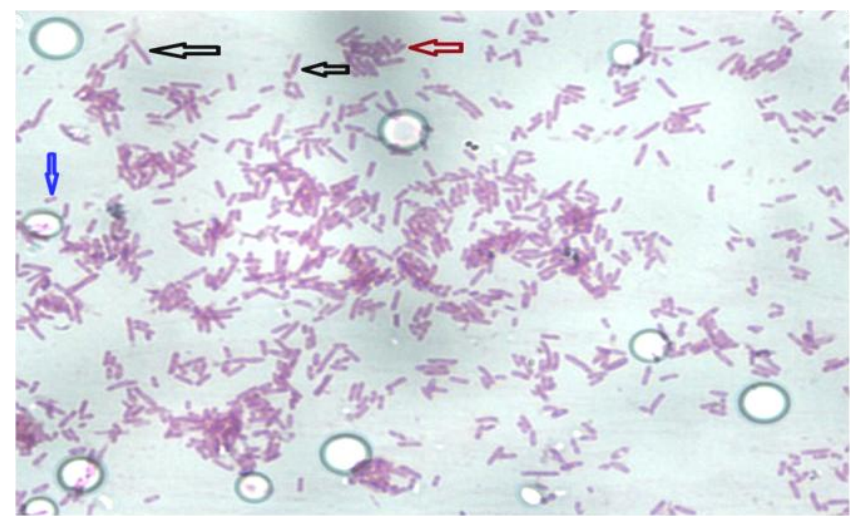




\section{Haemolytic Activity}

The hemolytic activity, more widely known as the Kanagawa phenomenon, is one of the important virulence markers. Red blood cell of the host organism is lysed due to the presence of hemolysin gene which in turn helps in the spread of the pathogen in the host blood. The hemolytic activity of $E$. coli is related to the presence of hemolysin genes (Lovell and Rees, 1960; Smith, 1963; Snyder and Koch, 1966). In this study, alpha hemolytic activity and $\beta$ hemolytic activity were detected in isolates of $E$. coli on blood agar plates. Emergence of characteristic flat, transparent, $\beta$-haemolytic colonies on secondary blood agar plates inoculated from primary BA culture plates, initially inoculated with infected large intestine tissues of diseased bird, indicated towards the presence of Enterohaemorrhagic E. coli (EHEC) - identified on the basis of $\beta$ haemolysis, as shown in figure 2 .

Smith and Berrange (2006) reported high prevalence of $E$. coli in crop samples.

Srinivasan et al. (2003) reported maximum percentage of positive cases from heart blood swab followed by liver, spleen and bursa. No published inland report on avian colibacillosis is available to compare the results but Sharma and Kaushik (1986) and Mahajan et al., (1994) reported E. coli infections as principal disease in broilers in Haryana State, India.

The clinical signs of avian colibacillosis in birds comprised inappetence, droopy head, respiratory distress, watery diarrhea which in some cases was blood tinged, pasting vent, ruffled feathers, occasionally lameness and stunted growth. The clinical findings of colibacillosis in broiler birds recorded in this study are in confirmity with the earlier reports of Kaul et al., (1992) who reported an outbreak of colibacillosis with clinical signs in broiler chicks.

Early chick mortality from two-day-old up to 12-day-old caused by $E$. coli infection might be transmitted through fecal contamination of egg shell, followed by penetration and ovarian infection or salpingitis (Calnek et al., 1997; Mukhopadhyay et al., 1999). Calnek et al., (1997) described the increased incidence of E. coli infection shortly after hatching which reduced after about six days. The observations of clinical signs and lesions in layers or fowls of the selected poultry farm in Ajmer region indicate both horizontal and egg transmission of E. coli in fowls (layers). The pathological lesions of avian colibacillosis are varied and wide, and have been reported to be included omphalitis and yolk sac infection, air sacculitis, pericarditis, salpingitis, peritonitis, enteritis, and colisepticemia. In this study, omphalitis and yolk sac infection, fibrinous pericarditis, fibrinous perihepatitis, dark and congested liver and air sacculitis or caseated and translucent air sacs were recorded in layer birds. These lesions observed in the present study are in conformity with the earlier reports of Kaul et al. (1992), Calnek et al. (1997) Haider et al. (2004), Islam et al. (2004) and Khaton et al., (2008).

Considering the higher mortality rates in layers of selected poultry farms and external traits and symptoms developed in sick layers and abnormal behavior of diseased layers and clinical signs and postmortem lesions in necropsied layers, caused by Escherichia coli. Colibacillosis may be considered as a threat to the layer industry in Ajmer region. The present study was then extended further to microbiological research work to confirm the results.

Therefore, these disease problems can be checked by adopting sound management, good sanitation and judicious selection of 
antibiotic based on further antibiogram studies which is recommended to the poultry owners of Ajmer region. Such high mortality in layers and high frequency of the incidence of infectious bacterial diseases in layers pointed towards the illiteracy of poultry farmers in Ajmer region especially of remote and village areas and unawareness of scientific methods and technology used by them in poultry industry. Attention is to be paid for personal hygiene in processing and handling of poultry and poultry products.

\section{Acknowledgement}

We gratefully acknowledge the technical assistance of Dr. V. K. Mishra, Retired Govt. Veterinary Doctor, Ajmer in performing necropsy of birds and his invaluable advice and encouragement in preparing the manuscript.

\section{References}

Almeida, F.S., et al. 2007. Diarréia Suína: estudo da etiologia, virulência e resistência a antimicrobianos de agentes isolados em leitões na região de Ribeirão Preto-SP, Brasil. ARS Veterinaria, 23: 151-157.

Calnek, B.W., Barnes, H.J., Beard, C.W., McDougald, L.R., Saif, Y.M. 1997. Diseases of Poultry. Iowa State University Press, Ames, Iowa, USA.

Cruickshank, R., Dugid, J.P., Marmion, B.P., Swain, R.H.A. 1975. Medical Microbiology. 12th ed., Churchill Living Stonne, Edinburgh, London and New York. Vol. 2, pp. 170.

Edwards, P.R., Ewing, W.H. 1972. Identification of Enterobacterioceae. 3rd ed. Burgess Publishing Co., Minneapolis, Minnesota- 55415.

Greenberg, R.N., Guerrant, R.L. 1986. Heat stable enterotoxin. In: Pharmacology of bacterial toxins. (Eds.) F. Dorner and J. Drews. Pergamon Press, Elmsford, New York. pp. 115-151.

Haider, M.G., Rahman, M.M., Hossain, M.M., Rashid, M., Sufian, M.A., Islam, M.M., Haque, A.F.M.H. 2004. Production of formalin killed fowl typhoid vaccine using local isolates of Salmonella gallinarum in Bangladesh. Bangladesh J. Vet. Med., 5(1/2): 33-38.

Islam, M.T., Islam, M.A., Samad, M.A., Kabir, S.M.L. 2004. Characterization and antibiogram of Escherichia coli associated with mortality in broilers and ducklings in Bangladesh. Bangladesh J. Vet. Med., 2(1): 0914.

Jawetz, E.J., Melnick, Adelberg, E.A. 1984. Review of Medical Microbiology. 16th Edn. Lange Medical Publication, California, pp: 122-144.

Kabir, S.M.L. 2010. Avian Colibacillosis and Salmonellosis: A Closer Look at Epidemiology, Pathogenesis, Diagnosis, Control and Public Health Concerns. Int. J. Environ. Res. Pub. Health, 7: 89-114.

KaulL, Kaul, P.L., Shah, N.M. 1992. An outbreak of colibacillosis in broiler chicks at an organized poultry farm under semi-arid zone of north Gujarat. Ind. Vet. J., 69: 373-374.

Khaton, R., Haider, M.G., Paul, P.K., Das, P.M., Hossain, M.M. 2008. Colibacillosis in commercial chickens in Bangladesh. Bangladesh Vet. 25(1): 17-24.

Levine, M. 1987. Escherichia coli that cause diarrhea: enterotoxigenic, enteropathogenic, enteroinvasive, enterohemorrhagic and enteroadherent. J. Infec. Dis., 155: 377-390.

Lovell, R., Rees, T.A. 1960. A filterable haemolysin from Escherichia coli. 
Nature, 188: 755-756.

Mahajan, N.K., Jindal, N., Kulshreshtha, R.C. 1994. Major broiler diseases in some parts of Haryana. Ind. J. Ani. Sci., 64: 1118-1122.

Mukhopadhyay, H.K., Dorairajan, N., George, V.T., Chandran, N.D.J. 1999. Pathology of the reproductive organs of layer birds in Escherichia coli infection. Ind. J. Ani. Sci., 69: 39-40.

Pelczar, Z.R., Chan, E.C.S., Kreig, N.R. 1993.The microscopic examination of Microorganisms In: Microbiology, 5th edn. Tata McGraw-Hill Publishing com. Ltd. New Delhi. pp. 66-67.

Porter, R.E.J.R. 1998. Bacterial Enteritides of Poultry. Poul. Sci. 77: 1159-1165.

Rahman, M.T., Saha, S., Islam, M.A. 1999. Prevalence of salmonella in poultry feed of Mymensingh, Bangladesh. The Bangladesh Vet., 16: 45-46.

Saleh, M., Seedorf, J, Hartung, J. 2003.
Total count of bacteria in the air of three different laying hen housing systems. Dtsch. Tierarztl. Wochenschr., 110(9): 94-97.

Sharma, N.K., Kaushik, R.K. 1986. Surviellance of diseases in Haryana State. Ind. J. Ani. Sci., 56: 762-764.

Smith, H.W. 1963. The hemolysins of Escherichia coli. J. Pathol. Bacteriol., 85: 197-211.

Snyder, I.S., Koch, N.A. 1966. Production and characteristics of hemolysins of Escherichia coli. J. Bacteriol., 91: 763-767.

Srinivasan, P., Sudhakar, Rao, G.V., Titus George, V. 2003. Serotyping of Escherichia coli isolated from natural cases of colibacillosis in chicken in and around Namakkal. Ind. Vet. J., 80(2): 192-193.

Stordeur, P., Mainil, J. 2002. La colibacillose antibiotics. aviaire. Annales de Médecine Vétérinaire. 146: $11-18$.

\section{How to cite this article:}

Tripti Dadheech, Reena Vyas, Vijaylatha Rastogi. 2016. Prevalence, Bacteriology, Pathogenesis and Isolation of E. coli in Sick Layer Chickens in Ajmer Region of Rajasthan, India. Int.J.Curr.Microbiol.App.Sci. 5(3): 129-136. doi: http://dx.doi.org/10.20546/ijcmas.2016.503.018 